\title{
GAMBARAN KADAR CHOLINESTERASE DARAH PETANI PENYEMPROT PESTISIDA DI DESA BOLANG KABUPATEN KARAWANG JAWA BARAT
}

\author{
Siska Ayu Lestari ${ }^{1 *}$, Melania Perwitasari ${ }^{2}$, Siti Nurfajriah ${ }^{3}$ \\ 1. Program Studi DIII Teknologi Laboratorium Medik, STIKes Mitra Keluarga, Bekasi-Indonesia \\ 2. Program Studi S1 Farmasi, STIKes Mitra Keluarga, Bekasi-Indonesia \\ 3. Program Studi DIII Teknologi Laboratorium Medik, STIKes Mitra Keluarga, Bekasi-Indonesia \\ *Korespondensi: Siska Ayu Lestari | STIKes Mitra Keluarga | siskalestari29@ gmail.com
}

\begin{abstract}
Abstrak
Pendahuluan: Pestisida merupakan semua zat kimia serta jasad renik dan virus yang dipergunakan untuk membunuh, mencegah, dan mengusir hama. Pestisida juga digunakan untuk merangsang, mengatur, serta mengendalikan tumbuhan. Pestisida dapat memberikan efek buruk menyangkut kesehatan manusia yaitu peristiwa keracunan akut maupun kronik. Penelitian ini dilakukan untuk mengetahui gambaran kadar cholinesterase darah petani penyemprot pestisida di Desa Bolang Kabupaten Karawang Jawa Barat.

Metode: Penelitian dilakukan pada bulan April 2018. Metode penelitian yang digunakan adalah cross-sectional.

Hasil: Hasil data uji deskriptif diperoleh kadar cholinesterase darah petani di Desa Bolang mempunyai kadar cholinesterase normal sebanyak 29 orang $(100,0 \%)$. Nilai rata-rata kadar cholinesterase darah petani di Desa Bolang yaitu 7.515,86 U/L

Kesimpulan: Bahwa petani penyemprot pestisida di Desa Bolang Kabupaten Karawang Jawa Barat tahun 2018 tidak ada yang masuk dalam kategori keracunan pestisida.
\end{abstract}

Kata Kunci: Cholinesterase, Insektisida, Karbamat, Organofosfat, Pestisida.

Diterima 21 September 2019; Accepted 30 Desember 2019

\section{PENDAHULUAN}

Pertanian merupakan salah satu bidang terpenting dalam memenuhi kebutuhan hidup masyarakat. Pemenuhan kebutuhan akan bahan makanan tersebut yang dalam jumlah besar tidak mungkin tanpa adanya gangguan dari hama. Penggunaan pestisida merupakan salah satu upaya yang dapat dilakukan untuk mengatasi hal tersebut.

Menurut Peraturan Menteri Pertanian Republik Indonesia Nomor: 39 / Permentan / SR.330 / 7 / 2015, pestisida adalah semua zat kimia dan bahan lain serta jasad renik dan virus yang dipergunakan untuk memberantas atau mencegah hama-hama dan penyakit yang merusak tanaman, bagian-bagian tanaman atau hasil-hasil pertanian (Permentan, 2015). Meskipun pestisida bermanfaat bagi pertanian, namun pestisida dapat bersifat racun bagi manusia khususnya petani penyemprot pestisida. Ada tidaknya keracunan pestisida pada petani dapat dilihat dari nilai kadar cholinesterase (CHE) dalam darah. Semakin rendah kadar CHE menunjukkan adanya keracunan akibat penggunaan pestisida (Rahmawati \& Martiana, 2014). Kadar CHE dalam darah dapat digunakan sebagai indikator keracunan psestisida organofosfat.

Cholinesterase (CHE) adalah suatu enzim dari katalisis biologik di dalam jaringan tubuh yang berperan untuk menjaga otot, kelenjar, dan saraf bekerja secara terorganisir dan harmonis. Pestisida golongan organofosfat berperan sebagai inhibitor irreversible, ketika mengikat enzim CHE ikatan antara inhibitor dengan enzim tidak dapat dipisahkan dari sisi aktif enzim (Depkes RI, 1992). Keadaan ini menyebabkan enzim tidak dapat mengikat asetilkolin, sehingga terjadi akumulasi asetilkolin dalam jumlah besar (Depkes RI, 1992). Penurunan aktivitas enzim CHE dapat mengakibatkan terganggunya sistem saraf, keracunan, hingga dapat menyebabkan kematian (Depkes RI, 1992).

Penduduk Desa Bolang Kecamatan Tirtajaya Kabupaten Karawang Jawa Barat sebagian besar mempunyai mata pencaharian sebagai petani. Berdasarkan pengamatan peneliti para petani tidak menggunakannya alat pelindung diri (APD) seperti masker, sarung tangan maupun kacamata saat penyemprotan sawah. Keluhan yang dirasakan oleh petani antara lain mata perih, pusing atau sakit kepala setelah melakukan penyemprotan dengan pestisida. Hal ini dapat menjadi potensi ada kemungkinan terjadinya keracunan pestisida. Pengukuran kadar CHE terhadap darah petani penyemprot pestisida di Desa Bolang dilakukan untuk mengetahui ada tidaknya keracunan pestisida organofosfat. 


\section{METODE}

Jenis penelitian ini adalah penelitian deskriptif dan menggunakan metode pengambilan sampel studi potong lintang atau cross-sectional. Penelitian dilakukan dari tanggal 18 April - 28 April 2018. Tempat penelitian dilakukan di Laboratorium Kimia Klinik STIKes Mitra Keluarga.

Populasi target adalah petani yang melakukan penyemprotan pestisida di Desa Bolang Kecamatan Tirtajaya Kabupaten Karawang Jawa Barat. Besar sampel yang digunakan 46 orang petani penyemprot pestisida. Pengambilan sampel menggunakan sampling no random pada semua petani penyemprot pestisida yang masuk dalam kriteria inklusi.

Kriteria inklusi terdiri dari laki-laki dan perempuan berusia 20 - 70 tahun, petani penyemprot pestisida yang tinggal di Desa Bolang Kecamatan Tirtajaya Kabupaten Karawang Jawa Barat hingga saat dilakukannya penelitian, bersedia untuk diwawancara, bersedia untuk diambil sampel darahnya, dan menggunakan pestisida golongan organofosfat atau karbamat. Kriteria eksklusi terdiri dari perempuan hamil, laki-laki dan perempuan yang berusia $<20$ tahun atau $>70$ tahun, bukan petani penyemprot pestisida yang tinggal di Desa Bolang Kecamatan Tirtajaya Kabupaten Karawang Jawa Barat hingga saat dilakukannya penelitian, tidak bersedia untuk diwawancara, tidak bersedia untuk diambil sampel darahnya, dan tidak menggunakan pestisida golongan organofosfat atau karbamat.

Variabel penelitian terdiri dari variabel dependent yaitu kadar cholinesterase dalam darah petani dan variabel independent yaitu jenis pestisida, karakteristik individu (umur, jenis kelamin, status kesehatan dan tingkat pengetahuan), lama pajanan (lama penyemprotan, frekuensi penyemprotan, suhu dan waktu penyemprotan), serta perilaku (penggunaan alat pelindung diri (APD), dosis pestisida, arah kecepatan angin, kebiasaan merokok, kebiasaan mencuci tangan dan kebiasaan mandi).

Peralatan yang digunakan adalah lembar persetujuan (lembar informed consent), kuesioner, photometer semi-auto chemistery analyzer BA-88A untuk mengukur cholinesterase dalam serum. Peralatan lain yang digunakan dalam pemeriksaan kadar CHE antara lain spuit $3 \mathrm{ml}$ (Syringe), tabung vacutainer plain $3 \mathrm{ml}$ (Onemed), kapas alkohol 70\% (Onemed), tourniquet (General Care), tabung reaksi (Pyrex), sentrifus (GemmyPLC-03), cup serum, mikropipet adjust (Socorex) dengan ukuran $10 \mu 1,50 \mu 1,500 \mu 1$ dan $1.000 \mu$ l, yellow tip (Onemed), blue tip (Onemed), white tip (Onemed), label, dan timer.

Bahan yang digunakan dalam penelitian yaitu reagen $(\mathrm{R})$ cholinesterase dengan komposisi $\mathrm{R} 1=\mathrm{Buffer}$ / chromogen, Fosfat penyangga $50 \mathrm{mmol} / \mathrm{L} \mathrm{pH} \mathrm{7,7} \mathrm{DMNB} \mathrm{0,25} \mathrm{mmol} \mathrm{/} \mathrm{L} \mathrm{(Bubuk),} \mathrm{R2} \mathrm{=} \mathrm{Substrat,}$ Butyrylthiocholine iodida $7 \mathrm{mmol} / \mathrm{L}$ (beku-kering) dan R3 = Dibucaine, Dibucaine chorhidrate 2,6 mmol / L (Glory Diagnostics, 2017). Bahan lain yang digunakan untuk penelitian kali ini adalah aquadest dan sampel serum sebanyak 46 sampel.

Tahapan praanalitik diawali dengan pengambilan darah vena dilakukan setelah pengisian kuesioner dan wawancara. Alat dan bahan yang akan digunakan dipersiapkan. Pasien dipersiapkan dengan mengecek identitas responden dengan melihat kartu tanda penduduk (KTP). Identitas pasien dituliskan pada tabung vacutainer. Darah vena diambil sebanyak $3 \mathrm{cc}$ dan dimasukkan darah ke dalam tabung vacutainer secara perlahan. Sampel didiamkan pada suhu ruang selama 15 menit atau sampai membeku, lalu dipisahkan serum dari komponen darah dengan cara memasukkan sampel ke alat sentrifugasi. Alat sentrifugasi dioperasikan pada kecepatan $3.000 \mathrm{rpm}$ selama 10 menit. Serum yang terbentuk dimasukkan ke dalam cup serum dan dituliskan identitas sampel pada cup serum. Cup serum dimasukan ke dalam coolbox untuk menjaga kestabilan cholinesterase dalam serum. Sampel dibawa ke laboratorium kimia klinik STIKes Mitra Keluarga untuk diperiksa.

Tahapan analitik dilakukan dengan pemeriksaan dengan bahan kontrol normal, bahan kontrol patologis, dan sampel responden. Reagen 1 (R1) dipipet sebanyak 1,5 ml dan dimasukkan ke dalam 3 tabung reaksi. Bahan kontrol normal, bahan kontrol patologis, dan sampel responden ditambahkan sebanyak $10 \mu \mathrm{l}$ ke dalam masing-masing tabung reaksi dan homogenkan. Reagen 2 (R2) ditambahkan sebanyak $50 \mu 1$ ke dalam masing-masing tabung reaksi dan homogenkan. Setelah homogen, segera dibaca pada alat photometer semi-auto chemistery analyzer BA-88A dengan panjang gelombang $405 \mathrm{~nm}$ suhu $37^{\circ} \mathrm{C}$. Konsentrasi cholinesterase yang muncul pada layar alat dicatat. Tahapan paska analitik dilakukan dengan cara hasil pemeriksaan kadar cholinesterase darah dicatat pada semua sampel dan memasukkannya ke dalam program komputer SPSS versi 20.

Etika pengambilan data dalam penelitian ini dilakukan dengan cara responden bersedia mengikuti 
penelitian dan telah mengetahui hak dan kewajibannya sebagai responden yang dinyatakan dengan pengisian informed consent.

\section{HASIL}

Keterbatasan yang dihadapi adalah jumlah sampel saat peneliti melakukan proses pengambilan darah, dari 46 orang total petani yang bersedia diambil darahnya hanya 36 orang petani yang hadir untuk diambil darahnya. Sepuluh orang petani sisanya telah pergi ke sawah di pagi hari yang menyebabkan tidak dapat hadir saat dilakukan pengambilan darah. Dari jumlah 36 petani setelah dilakukan wawancara dan kuesioner hanya berjumlah 29 sampel petani yang menggunakan pestisida golongan organofosfat.

Berdasarkan hasil pemeriksaan 29 orang petani penyemprot pestisida di Desa Bolang yang masuk dalam kriteria inklusi, didapatkan kadar cholinesterasenya yang dapat dilihat pada tabel dibawah ini:

Tabel 1. Distribusi Mean, Median, SD, Minimum dan Maximum Kadar Cholinesterase Darah Petani di Desa Bolang

\begin{tabular}{llllll}
\hline Variabel & Mean & Median & SD & Minimum & Maximum \\
\hline Kadar Cholinesterase (U/L) & $7.515,86$ & $7.361,00$ & $2.253,873$ & 2.651 & 12.106 \\
\hline
\end{tabular}

Berdasarkan Tabel 1 dapat diketahui bahwa rata-rata kadar cholinesterase dalam darah petani adalah 7.515,86 U/L dengan standar deviasi 2.253,873 U/L. Kadar cholinesterase terendah adalah 2.651 U/L dan kadar cholinesterase tertinggi adalah $12.106 \mathrm{U} / \mathrm{L}$. Kadar cholinesterase dalam darah pada penelitian ini diperoleh dari hasil pemeriksaan cholinesterase dengan menggunakan metode enzymatic colorimetric method kinetik untuk mengukur cholinesterase total dan inhibited dalam serum petani penyemprot pestisida dengan alat photometer semi-auto chemistery analyzer BA-88A. Hasil kontrol harian pada saat dilakukan penelitian didapatkan hasil kontrol normal yaitu 4.845,9 U/L dengan rentang nilai normal kontrol yaitu 4.010-6.028 U/L. Hasil kontrol patologis didapatkan hasil yaitu 4.824,3 U/L dengan rentang nilai kontrol yaitu 4.059-6.101 U/L. Hasil pemeriksaan kadar cholinesterase dikelompokkan menjadi 4 kriteria dengan klasifikasi dari Departemen Kesehatan RI yaitu normal ( $\geq 75 \%$ dari nilai normal), keracunan ringan ( $\geq 50 \%$ - $<75 \%$ dari nilai normal), keracunan sedang ( $\geq 25 \%$ - $50 \%$ dari nilai normal) dan keracunan berat (<25\% dari nilai normal) (Depkes RI, 1989).

Tabel 2. Klasifikasi Kadar Cholinesterase Darah Petani Penyemprot Pestisida di Desa Bolang

\begin{tabular}{lll}
\hline Kadar Cholinesterase & Jumlah (n) & Persentase (\%) \\
\hline Normal (>75\%) & 29 & 100,0 \\
Jumlah & 29 & 100,0 \\
\hline
\end{tabular}

Tabel 2 menunjukkan bahwa dari 29 petani penyemprot pestisida di Desa Bolang yang hadir, semua petani memiliki kadar cholinesterase normal yaitu 29 orang (100\%) petani. Angka ini menunjukkan bahwa petani penyemprot pestisida di Desa Bolang Kecamatan Tirtajaya Kabupaten Karawang Jawa Barat tahun 2018 tidak mengalami keracunan pestisida.

Tabel 3. Univariat Variabel Penelitian Petani Penyemprot Pestisida di Desa Bolang

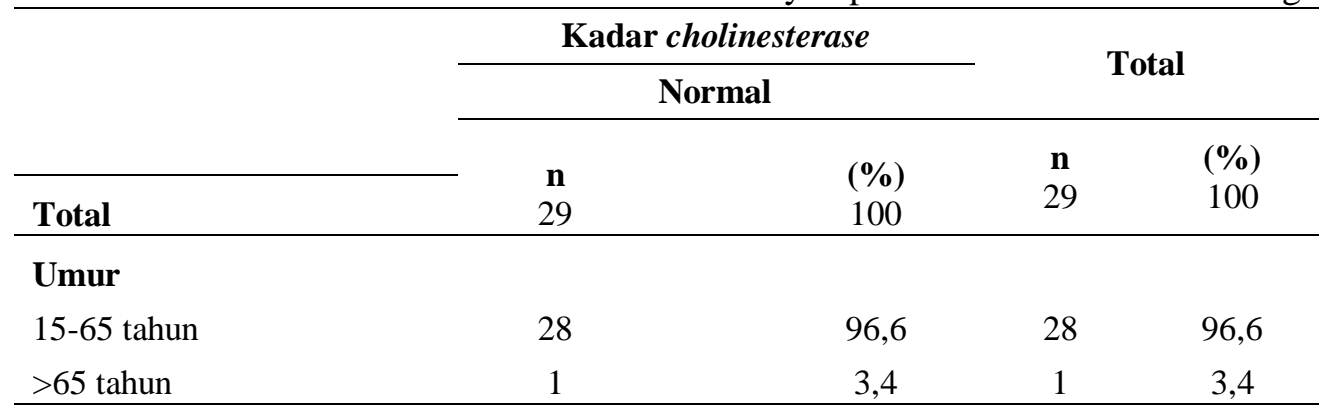

Jenis kelamin 


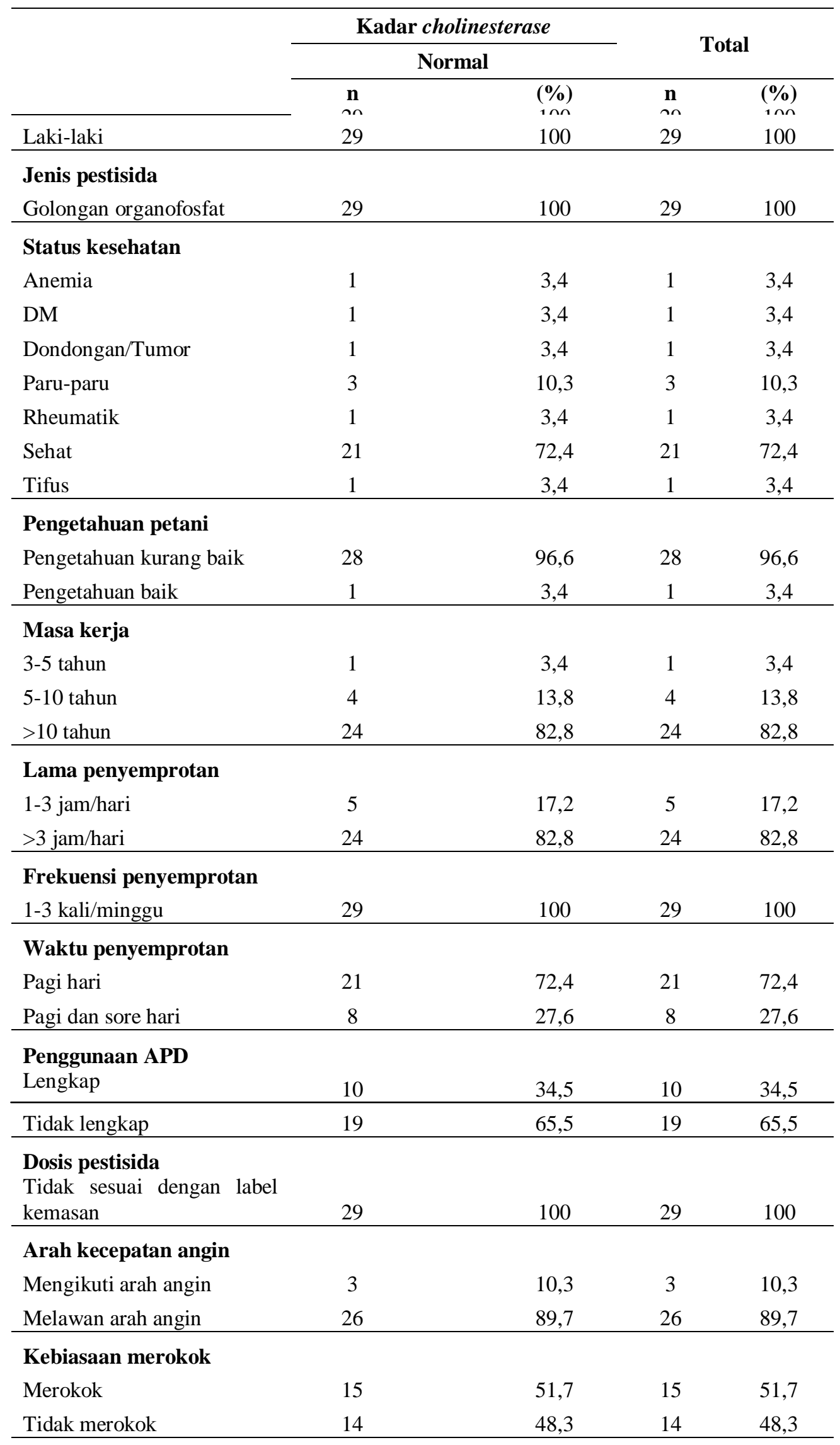

Kebiasaan mandi petani 


\begin{tabular}{|c|c|c|c|c|}
\hline & \multicolumn{2}{|c|}{ Kadar cholinesterase } & \multirow{2}{*}{\multicolumn{2}{|c|}{ Total }} \\
\hline & \multicolumn{2}{|c|}{ Normal } & & \\
\hline & $\underset{n n}{\mathbf{n}}$ & $\begin{array}{l}(\%) \\
1 \text { ) }\end{array}$ & nn & $\begin{array}{c}(\%) \\
10 n\end{array}$ \\
\hline Baik $\geq 2$ kali dalam sehari & 29 & 100 & 29 & 100 \\
\hline \multicolumn{5}{|l|}{ Kebiasaan mencuci tangan } \\
\hline Baik & 29 & 100 & 29 & 100 \\
\hline
\end{tabular}

\section{PEMBAHASAN}

Hasil pemeriksaan cholinesterase darah yang merujuk pada Tabel 1, diketahui bahwa kadar terendah kadar cholinesterase darah yaitu $2.651 \mathrm{U} / \mathrm{L}$. Nilai rujukan normal pemeriksaan cholinesterase darah adalah 3.500-8.500 U/L untuk laki-laki (Glory Diagnostics, 2017). Kadar cholinesterase terendah tersebut tidak masuk dalam kategori keracunan dikarenakan berdasarkan klasifikasi dari Departemen Kesehatan RI dikatakan normal apabila kadar cholinesterase $\geq 75 \%$ dari nilai normal (Depkes RI, 1989).

Tabel 2 menunjukkan bahwa dari 29 petani penyemprot pestisida di Desa Bolang yang hadir, semua petani memiliki kadar cholinesterase normal yaitu 29 orang (100\%) petani. Persentase yang didapatkan dari hasil penelitian primer ini lebih tinggi dari penelitian tahun 2013 di 3 Desa pada 2 wilayah kerja UPTD Puskesmas di Kabupaten Karawang dengan hasil 81\% petani mempunyai kadar cholinesterase normal atau tidak mengalami keracunan pestisida (Suwardi, 2013).

Meskipun kadar cholinesterase darah petani normal, petani di Desa Bolang mengalami beberapa gejala yang memungkinkan terjadinya keracunan akibat dari terpaparnya pestisida. Gejala yang dialami meliputi perih pada mata, pusing atau sakit kepala, dan mual. Petani di Desa Bolang mempunyai kadar cholinesterase darah yang normal dapat dikarenakan: (1) toksisitas klinis pestisida orgonofosfat terjadi 30 menit sampai 2 jam setelah penyemprotan. Kadar cholinesterase di dalam plasma dan sel darah merah akan berkurang sebanyak 50\% dari normal karena pemeriksaan cholinesterase digunakan untuk mendeteksi toksisitas keracunan akut akibat pestisida. Tanpa dilakukan terapi atau pengobatan, kadar CHE darah akan kembali normal dalam waktu 4-5 minggu (Harrison, 2000); (2) berbagai macam status kesehatan yang dimiliki oleh petani di Desa Bolang tidak mempengaruhi kadar CHE darahnya. Secara teori kadar CHE rendah biasanya ditemukan pada seseorang yang menderita penyakit hepatitis, sirosis, karsinoma metastatik pada hati, penyakit kuning obstruktif, infark miokardium, dermatomiositis, dan aklonestesemia genetik (Davidson \& Henry, 1976); (3) petani di Desa Bolang melakukan penyemprotan hama 1 kali dalam seminggu. Frekuensi ini masih masuk dalam kategori tidak sering yang menjadi salah satu faktor kadar CHE petani di Desa Bolang normal. Petani yang semakin sering melakukan penyemprotan akan lebih besar risiko keracunan karena menyebabkan residu pestisida dalam tubuh manusia menjadi lebih tinggi. Petani yang melakukan penyemprotan pestisida $\geq 2$ kali dalam seminggu memiliki risiko 4,95 kali lebih tinggi untuk mengalami keracunan (Mualim, 2002); (4) dosis yang digunakan petani di Desa Bolang untuk pestisida bubuk adalah 1-2 sendok makan atau sekitar 20-30 gram untuk sekitar 15 liter dan nantinya akan ditambahkan dengan pestisida jenis golongan lain. Dosis yang digunakan lebih kecil dari dosis yang dianjurkan. Penggunan dosis pestisida tanpa mengikuti label instruksi kemasan pestisida meningkatkan risiko keracunan akut sebesar 1,61 kali lebih besar dibandingkan dengan yang mengikuti label instruksi kemasan pestisida (Kim, Cha, Ko, \& Kim, 2013); (5) petani yang merupakan perokok aktif memiliki kebiasaan baik yaitu merokok sebelum atau sesudah melakukan penyemprotan pestisida, tidak merokok pada saat melakukan penyemprotan pestisida. Petani yang sudah selesai melakukan penyemprotan, bila akan merokok memiliki kebiasaan baik yaitu selalu mencuci tangan terlebih dahulu, sehingga masuknya pestisida ke dalam tubuh menjadi sedikit kemungkinan.

Berdasarkan pembahasan diatas tersebut ada kemungkinan faktor-faktor yang dapat mempengaruhi kadar cholinesterase darah petani yang kedepannya perlu diperhatikan lebih lanjut. Faktor-faktor ini apabila tidak ditinjaklanjuti dapat memungkinkan terjadinya keracunan pada petani di Desa Bolang. Adapun faktor yang perlu diperhatikan diantaranya yaitu jenis pestisida, dosis pestisida, penggunaan alat pelindung diri (APD), status kesehatan, pengetahuan petani, arah kecepatan angin, dan lama penyemprotan.

\section{KESIMPULAN}

Berdasarkan analisa dan pembahasan hasil penelitian yang telah dilakukan pada petani penyemprot 
pestisida di Desa Bolang Kecamatan Tirtajaya Kabupaten Karawang Jawa Barat tahun 2018 dapat disimpulkan bahwa petani penyemprot pestisida di Desa Bolang Kecamatan Tirtajaya Kabupaten Karawang Jawa Barat tahun 2018, sebanyak 29 orang $(100,0 \%)$ petani memiliki kadar cholinesterase normal. Nilai rata-rata kadar cholinesterase darah petani di Desa Bolang yaitu 7.515,86 U/L, hal ini menunjukkan bahwa petani penyemprot pestisida tidak ada yang masuk dalam kategori keracunan pestisida.

\section{UCAPAN TERIMA KASIH}

Terima kasih kami ucapkan kepada Bapak Jaenudin selaku Kepala Desa Bolang Kecamatan Tirtajaya Kabupaten Karawang Jawa Barat yang telah memberikan dukungan dalam pelaksanaan penelitian di Desa Bolang. Terima kasih juga kami ucapkan kepada STIKes Mitra Keluarga yang telah mendukung terlaksananya penelitian ini melalui penyediaan sarana dan prasarana.

\section{REFERENSI}

Davidson, I., \& Henry, J. B. 1976. Clinical Diagnostic by Laboratory Methods. London: WB. Saunders Co.

Depkes RI. 1989. Toksikologi untuk Sekolah Menengah Analis Kesehatan. Jakarta: Pusat Pendidikan Tenaga Kesehatan Departemen Kesehatan RI.

Depkes RI. 1992. Pengenalan dan Penatalaksanaan Keracunan Pestisida. Jakarta: Departemen Kesehatan RI Direktorat Jenderal PPM \& PLP.

Glory Diagnostics. 2017. Cholinesterase Total and Inhibited. Insert Kit Glory Diagnostic.

Harrison. 2000. Prinsip-prinsip Ilmu Penyakit Dalam. Edisi 13 Volume 5. Jakarta: Buku Kedokteran EGC.

Kim, J., Cha, E., Ko, Y., \& Kim, D. 2013. Work-Related Risk Factors by Severity for Acute Pesticide Poisoning Among Male Farmers in South Korea. International Journal Of Enviromental Research and Public Health, 1100-1112.

Mualim, K. 2002. Analisis Faktor Risiko yang Berpengaruh terhadap Keracunan Pestisida Organophospat pada Petani Penyemprot Hama Tanaman di Kecamatan Bulu Kabupaten Temanggung. Jurnal Ilmu Kesehatan Lingkungan, 56-60.

Permentan. 2015. Peraturan Menteri Pertanian Tentang Pendaftaran Pestisida. Jakarta: Peraturan Menteri Pertanian Republik Indonesia.

Rahmawati, Y. D., \& Martiana, T. 2014. Pengaruh Faktor Karakteristik Petani dan Metode Penyemprotan Terhadap Kadar Kolinesterase. The Indonesian Journal of Occupational Safety, Health and Environment, 85-94.

Suwardi, S. 2013. Pajanan Pestisida Terhadap Aktivitas Cholinesterase Dalam Darah Petani Penyemprot Hama Padi di 3 Desa Pada 2 Wilayah Kerja UPTD Puskesmas di Kabupaten Karawang. Skripsi. Depok: Fakultas Kesehatan Masyarakat Universitas Indonesia. 